\title{
ANALISIS ASOSIASI MEREK, NILAI PRODUK, DAN KUALITAS PELAYANAN, SERTA PENGARUHNYA TERHADAP KEPUASAN DAN LOYALITAS KONSUMEN SEPEDA MOTOR DI BEKASI
}

\author{
Mohammad Rizan \\ Jurusan Manajemen Fakultas Ekonomi Universitas Negeri Jakarta \\ e-mail:dr_rizan@yahoo.com \\ Harun Arrasyid \\ Magister Manajemen Universitas Indonusa Esa Unggul \\ e-mail: Harunarrasyid_mm@yahoo.com
}

\begin{abstract}
The objectives of the research are: 1) to describe brand association, product value, service quality, consumer satisfaction and loyalty of motorcycle in Bekasi; 2) to test the influence of brand association, product value and service quality on consumer satisfaction; 3) to test the influence of brand association, product value, and service quality on consumer loyalty; 4) to test the influence of consumer satisfaction on consumer loyalty; 5) to test the simultaneous influence of brand association, product value, service quality on consumer satisfaction and loyalty. The research methods are descriptive and explanatory survey. Population are motorcycle consumer of Honda, Yamaha, and Suzuki in Bekasi. Observation unit are 200 consumer. Sampling technique is proportional stratified random sampling, research instrument is Likert's questionnaire, and analysis method is Structural Equation Modelling (SEM)/Lisrel 8.7 series. The descriptive research results indicate that dimension which strongly effect on brand association are behavior and benefit. Dimension which strongly effect on product value are cost, exchange value, esthetics and relative function. Dimension which strongly effect on consumer satisfaction are quality and total cost which must be paid. Dimension which strongly effect on consumer loyalty are repurchase, impenetrable to competitor, expand purchase, and recommend. The expalanatory/causal research results indicate that; 1) Brand association, product value, and service quality are significantly influenced on consumer satisfaction $(R 2=0.86)$; 2) Brand association, product value, and service quality are significantly influenced on consumer loyalty $(R 2=0.51)$; 3) Consumer satisfaction is significantly influenced on consumer loyalty $(R 2=0.62)$; 4) Brand association, product value and service quality are direct significantly influenced on consumer loyalty as well as indirectly through consumer satisfaction.
\end{abstract}

Keywords: brand association, product value, service quality, consumer satisfaction, and consumer loyalty.

\section{PENDAHULUAN}

Sepeda motor merupakan alat transportasi yang murah dan lebih fleksibel untuk menyusuri kemacetan jalan raya di Jakarta dibandingkan dengan menggunakan alat transportasi lainnya, seperti; penggunaan mobil tidak lebih efisien dibandingkan dengan sepeda motor. Hal ini dapat dilihat dengan makin banyaknya anggota masyarakat yang memilih sepeda motor sebagai 
alat transportasi dalam kehidupan sehari-hari dibandingkan dengan menggunakan mobil. Makin mahalnya harga bahan bakar minyak membuat masyarakat lebih realistis dalam memilih dan menggunakan alat transportasi dalam aktifitas sehari-hari. Populasi sepeda motor dari berbagai merek di Indonesia dapat terlihat pada tabel 1. Dari tabel 1 terlihat bahwa populasi sepeda motor di Indonesia mengalami kenaikan secara fluktuatif, dimana pada tahun 2006 mengalami penurunan akan tetapi mengalami kenaikan kembali secara signifikan pada tahun 2008. Jika diamati secara cermat terlihat pertumbuhan market share yang cukup signifikan terjadi pada sepeda motor merek Yamaha yang selalu mengalami kenaikan walaupun pesaing utamanya Honda yang berperan sebagai market leader mengalami penurunan pada tahun 2006 dan 2007.

Saat ini terdapat tujuh merek sepeda motor angota Asosiasi Industri Sepeda Motor (AISI) yang menguasai pasar yaitu Honda, Yamaha, Suzuki, Kawasaki, Kymco, Kanzen dan Piaggio. Dan sejak dikeluarkannya deregulasi tahun 2000 yang mengatur import sepeda motor secara utuh atau Completely Built-Up (CBU), maka muncul merek baru sepeda motor yang mayoritas berasal dari China, seperti; Beijing, Lifan, Sanex, Starway, Sumo, Wangguan, Xiangjiang, Xi Dong Li, Zong Shen, Garuda, Panda, dan Sundiro. Merek baru tersebut, meskipun jumlahnya sangat banyak tetapi mereka hanya memiliki market share kurang dari $5 \%$ dari total penjualan sepeda motor di Indonesia (www.wartaekonomi.com). Hal ini juga dapat dilihat dari makin sulitnya ditemui dealer motor China yang masih beroperasi.

Penelitian ini akan memfokuskan pada sepeda motor yang tergabung pada AISI dengan pertimbangan bahwa secara persentase jumlah penjualan motor yang tidak tergabung dalam AISI sangat kecil.
Nilai penjualan sepeda motor anggota AISI mengalami puncak penjualan pada tahun 2005 yaitu mencapai lebih dari 5 juta unit Honda dapat menjual 2,6 juta unit, Yamaha 1,2 juta unit, Suzuki 1 juta unit, Kawasaki 0,07 juta unit dan merek lainnya 0,03 juta unit. Penjualan sepeda motor di Indonesia masih didominasi oleh merek Jepang.

Perbedaan pangsa pasar antar merek yang menyolok disebabkan oleh perbedaan ekuitas merek (brand equity) dari masingmasing merek. Harga produk sebuah merek yang tinggi (skimming price) dan cenderung menanjak seakan-akan tidak dipengaruhi laju inflasi (Shocker dalam Andri Krisnanto, 2005). Persepsi kosumen tentang harga produk sebuah merek memiliki hubungan yang signifikan dengan kualitas produk dan pelayanan yang diperolehnya sehingga menimbulkan kepuasan. Saat ini merek Honda dinilai sebagai sepeda motor yang berharga lebih mahal dibandingkan dengan merek lainnya pada kelas yang sama. Namun harga yang dinilai lebih mahal ini tidak mengurangi minat konsumen untuk membeli sepeda motor Honda sehingga Honda masih memimpin dalam penjualan sepeda motor. Mayoritas konsumen masih loyal memilih Honda karena dianggap paling irit dan memiliki nilai jual kembali yang lebih tinggi dibandingkan merek lainnya. Sebagai contoh dengan tahun pembuatan yang sama yaitu tahun 2005, Honda Karisma 125cc saat ini harganya berkisar Rp 8,5 juta, lebih tinggi dibandingkan dengan merek lainnya seperti Yamaha Jupiter Z 125 cc berkisar Rp 8 juta.

Persaingan antar merek sepeda motor di Indonesia semakin meningkat ini juga ditandai dengan meningkatnya biaya iklan yang dikeluarkan oleh produsen sepeda motor. Pada tahun 2005 biaya iklan yang dikeluarkan sebesar 969 miliar rupiah naik pada tahun 2006 menjadi 1.229 miliar rupiah. Hal ini dilakukan produsen sepeda motor untuk mempertahankan dan mening- 
katkan jumlah konsumennya. Kepuasan konsumen sepeda motor merupakan hal yang sangat penting diperhatikan oleh produsen sepeda motor. Kepuasan konsumen sepeda motor dapat terwujud jika produsen dapat memenuhi keinginan konsumen. Keinginan konsumen dapat berupa produk yang bernilai guna, merek yang terpercaya, serta pelayanan dealer yang berkualitas.

Dengan melihat data pada Tabel 1., nampak terjadi pergeseran pemilihan merek dalam pembelian sepeda motor yang sebelumnya di dominasi merek Honda mulai diimbangi oleh Yamaha. Kesetiaan atau loyalitas pelanggan merupakan kunci dari perubahan pangsa pasar. Jika Honda mampu mempertahankan loyalitas pelanggan maka merek tersebut akan dapat terus mempertahankan dominasinya namun jika tidak maka hal ini merupakan kesempatan bagi merek lain untuk meningkatkan pangsa pasarnya. Yamaha sebagai penguasa pangsa pasar nomer dua merupakan ancaman nyata bagi merek Honda. Sebagai satu-satunya merek yang mampu menaikkan nilai penjualan pada tahun 2006, Yamaha memiliki peluang untuk meningkatkan pangsa pasar pada tahun 2007. Berdasarkan data penjualan periode Januari sampai dengan Maret 2007, merek Yamaha mulai mengurangi dominasi Honda. Dari data penjualan secara nasional tersebut terlihat bahwa terjadi perubahan market share dari Honda yang selalu mendominasi menjadi lebih berimbang dengan Yamaha.

Hal yang sama juga terjadi di pasar sepeda motor di wilayah Kabupaten Bekasi. Populasi sepeda motor yang terdaftar di Kantor Samsat Kabupaten Bekasi pada tabel 3.

Tabel 1: Populasi dan Market Share Sepeda Motor Di Indonesia Berdasarkan Merek Tahun 2005-2008 (dalam unit \& \%)

\begin{tabular}{ccccccc}
\hline TAHUN & Honda & Yamaha & Suzuki & Kawasaki & lainnya & TOTAL \\
\hline $\mathbf{2 0 0 5}$ & 2.648 .190 & 1.224 .595 & 1.091 .962 & 35.329 & 35.329 & 5.035 .405 \\
& $\mathbf{( 5 2 , 5 9 )}$ & $\mathbf{( 2 4 , 3 2 )}$ & $\mathbf{( 2 1 , 6 9 )}$ & $\mathbf{( 0 , 7 0 )}$ & $\mathbf{( 0 , 7 0 )}$ & $(\mathbf{1 0 0 )}$ \\
$\mathbf{2 0 0 6}$ & 2.340 .168 & 1.458 .561 & 568.041 & 33.686 & 26.379 & 4.426 .835 \\
& $\mathbf{( 5 2 , 8 6 )}$ & $\mathbf{( 3 2 , 9 5 )}$ & $\mathbf{( 1 2 , 8 3 )}$ & $\mathbf{( 0 , 7 6 )}$ & $\mathbf{( 0 , 6 0 )}$ & $(\mathbf{1 0 0 )}$ \\
$\mathbf{2 0 0 7}$ & 2.141 .015 & 1.833 .506 & 637.031 & 38.134 & 38.577 & 4.688 .263 \\
& $\mathbf{( 4 5 , 6 7 )}$ & $\mathbf{( 3 9 , 1 1 )}$ & $\mathbf{( 1 3 , 5 9 )}$ & $\mathbf{( 0 , 8 1 )}$ & $\mathbf{( 0 , 8 2 )}$ & $(\mathbf{1 0 0 )}$ \\
$\mathbf{2 0 0 8}$ & 2.874 .586 & 2.465 .546 & 793.758 & 44.690 & 98.234 & 6.276 .814 \\
& $\mathbf{( 4 5 , 8 0 )}$ & $\mathbf{( 3 9 , 2 8 )}$ & $\mathbf{( 1 2 , 6 5 )}$ & $\mathbf{( 0 , 7 1 )}$ & $\mathbf{( 1 , 5 6 )}$ & $\mathbf{( 1 0 0 )}$ \\
\hline
\end{tabular}

Sumber: AISI (data diolah)

Tabel 2: Penjualan Sepeda Motor Periode Januari - Oktober 2007

\begin{tabular}{cccc}
\hline No & Merek & Jumlah & \% \\
\hline 1 & Honda & 1.707 .531 & 44,90 \\
2 & Yamaha & 1.525 .822 & 40,12 \\
3 & Suzuki & 514.714 & 13,53 \\
4 & Lainnya & 54.901 & 1,44 \\
& Total & $\mathbf{3 . 8 0 2 . 9 6 8}$ & $\mathbf{1 0 0}$ \\
\hline
\end{tabular}

Sumber: AISI 
Jurnal Siasat Bisnis Vol. 12 No. 2, Agustus 2008 Hal: 129-147

Tabel 3: Populasi Sepeda Motor Di Kabupaten Bekasi Tahun 2005-2006

\begin{tabular}{llcccccc}
\hline \multirow{2}{*}{ No } & \multirow{2}{*}{ Merek } & \multicolumn{4}{c}{ Populasi } & \multicolumn{2}{c}{ Pertumbuhan } \\
& & $\mathbf{2 0 0 5}$ & Persentase & $\mathbf{2 0 0 6}$ & \% & Unit & \% \\
\hline 1 & Honda & 63.256 & $50,49 \%$ & 74.140 & 49,30 & 10.884 & 17,21 \\
2 & Kawasaki & 7.182 & $5,73 \%$ & 7.512 & 5,00 & 330 & 4,59 \\
3 & Kymco & 5.312 & $4,24 \%$ & 5.656 & 3,76 & 344 & 6,48 \\
4 & Piaggio & 3.226 & $2,57 \%$ & 3.254 & 2,16 & 28 & 0,87 \\
5 & Suzuki & 13.268 & $10,59 \%$ & 14.643 & 9,74 & 1.375 & 10,36 \\
6 & Yamaha & 30.185 & $24,09 \%$ & 42.163 & 28,04 & 11.978 & 39,68 \\
7 & Lainnya & 2.867 & $2,29 \%$ & 3.012 & 2,00 & 145 & 5,06 \\
& Total & $\mathbf{1 2 5 . 2 9 6}$ & $\mathbf{1 0 0 \%}$ & $\mathbf{1 5 0 . 3 8 0}$ & $\mathbf{1 0 0}$ & & \\
\hline
\end{tabular}

Sumber: Diolah dari data Kantor Samsat Bekasi

Jika dilihat dari tabel 3 di atas menunjukan bahwa market share Honda di Kabupaten Bekasi masih jauh mengungguli merek lainnya. Pada tahun 2006 populasi sepeda motor merek Honda adalah 49,30\%, kemudian diikuti berturut-turut Yamaha $28,04 \%$, Suzuki 9,74 \%, Kawasaki $5 \%$, Kymco 3,76 \%, Piaggio 2,16\% dan merek lainnya $2,0 \%$. Akan tetapi jika dilihat dari angka pertumbuhan populasi sepeda motor terlihat bahwa populasi merek Yamaha mengalami kenaikan paling tinggi sebesar 11.918 unit atau $39,68 \%$, kemudian diikuti Honda 10.884 unit atau $17,21 \%$, Suzuki 1.375 unit atau $10,36 \%$, dan merek lainnya sebagaimana tercantum pada tabel 3 di atas. Hal ini dapat mengindikasikan bahwa di Kabupaten Bekasi terjadi perubahan market share dari sebelumnya, dimana Yamaha mengalami kenaikan yang cukup signifikan meskipun Honda masih menjadi market leader.

Perubahan market share tersebut dapat terjadi karena adanya perubahan loyalitas konsumen sepeda motor. Jika sebelumnya konsumen selalu memilih Honda sebagai merek yang pilihan maka sekarang hal tersebut tidak berlaku mutlak. Yamaha mulai menjadi pesaing yang mampu mengimbangi dominasi Honda. Rifqi (2003) menunjukan bahwa loyalitas konsumen sepeda motor dipengaruhi secara signifikan oleh kepuasan konsumen. Kepuasan konsumen sepeda motor merupakan hal yang sangat penting diperhatikan oleh produsen sepeda motor. Kepuasan konsumen sepeda motor dapat terwujud jika produsen dapat memenuhi keinginan konsumen. Keinginan konsumen tersebut dapat berupa produk yang bernilai guna, merek yang terpercaya, pelayanan dealer yang berkualitas. Cronin dan Taylor (dalam Rizan, 2005; 169) menambahkan bahwa kepuasan konsumen dipengaruhi oleh kualitas pelayanan.

Dari data perubahan pangsa pasar merek sepeda motor dapat mengindikasikan bahwa telah terjadi penurunan kepuasan konsumen sepeda motor yang menyebabkan menjadi tidak loyal terhadap merek tersebut. Jika sebelumnya konsumen sepeda motor cenderung memilih merek Honda yang memiliki asosiasi merek sebagai merek yang paling irit maka saat ini konsumen mulai memilih merek Yamaha. Hal ini dapat disebabkan oleh keberhasilan edukasi Yamaha melalui iklannya yang menonjolkan kecepatan sepeda motor lebih utama dari pada bahan bakar yang hanya irit tetapi tidak signifikan. Di era yang menuntut penggunana waktu secara efisien ini maka konsumen membutuhkan sepeda motor yang dapat mengakomodasi hal ini. 
Berdasarkan latar belakang yang sudah diuraikan maka penulis merumuskan identifikasi beberapa masalah yang muncul, antara lain:

1. Bagaimana deskripsi asosiasi merek, nilai produk, kualitas pelayanan, kepuasan kepuasan pelayanan dan loyalitas pelanggan sepeda motor.

2. Apakah asosiasi merek, nilai produk dan kualitas pelayanan berpengaruh secara signifikan terhadap kepuasan kn sumen.

3. Apakah asosiasi merek, nilai produk dan kualitas pelayanan berpengaruh secara signifikan terhadap loyalitas kn sumen.

4. Apakah kepuasan konsumen berpengaruh secara signifikan terhadap loyalitas konsumen.

5. Apakah asosiasi merek, nilai produk dan kualitas pelayanan berpengaruh secara signifikan baik secara langsung ataupun melalui kepuasan terhadap loyalitas konsumen.

\section{KAJIAN PUSTAKA DAN PENGEMBANGAN HIPOTESIS Merek}

American Marketing Association mendefinisikan merek sebagai berikut: "Brand is a name, term, sign, symbol, or design, or a combination of them. Intended to identify the goods or services of one seller or group of sellers and to differentiate them from those of competitors" (Kotler, 2003: 187).

Selanjutnya Travis (2000: 93) menyatakan bahwa merek tidak hanya merupakan slogan, logo, simbol ataupun paten. Merek bukan sesuatu yang dibentuk di pabrik melainkan sesuatu yang dibentuk dalam pikiran konsumen melalui proses pemasaran secara keseluruhan. Pemberian merek ditujukan untuk memberikan sesuatu yang unik dan menarik dibandingkan pesaing, sehingga dapat memuaskan kebu- tuhan konsumen baik secara rasional maupun emosional. Pada saat seseorang memikirkan sebuah produk, mereka hanya mengaitkan dengan atribut serta manfaatnya. Sedangkan pada saat mereka membayangkan sebuah merek, mereka akan melibatkan dimensi emosional di dalamnya (Temporal, 2001: 83). Keller (2003: 183), selanjutnya, menjelaskan bahwa pengelolaan merek membutuhkan perspektif jangka panjang, dan dikelola secara aktif setiap waktu dengan penguatan merek atau jika dibutuhkan dengan revitalisasi merek.

\section{Asosiasi Merek}

Aaker (1994: 79) mendefinisikan asosiasi merek sebagai segala sesuatu yang terdapat di dalam ingatan atau memori seseorang mengenai suatu merek. Ingatan terhadap sebuah merek akan semakin meningkat seiring dengan makin seringnya mengkonsumsi suatu merek maupun mendapatkan informasi mengenai merek tersebut. Sejalan dengan penjabaran asosiasi merek, Keller (2003: 177) membagi tipe asosiasi merek menjadi tiga bagian: (1) Atribut yaitu sifat merek yang tidak nampak seperti persepsi harga, citra pengguna, personalitas merek, dan perasaan terhadap citra merek; (2) Manfaat yaitu manfaat yang diperoleh seorang konsumen ketika memilih, membeli dan menggunakan sebuah merek barang atau jasa; (3) Perilaku yaitu segala sesuatu yang berhubungan dengan tindakan atau perilaku yang dilakukan oleh konsumen terhadap sebuah merek barang atau jasa.

Aaker (1994: 84) berpendapat bahwa asosiasi merek dapat menciptakan nilai yang pada akhirnya menciptakan rasa puas di benak konsumen. Asosiasi merek menjadi pijakan konsumen dalam keputusan pembelian dan loyalitasnya pada merek tersebut. 


\section{Nilai Produk}

Kottler (2003: 73) mendefinisikan nilai pelanggan adalah perbedaan antara nilai pelanggan total dan biaya pelanggan total. Nilai total pelanggan adalah sekumpulan manfaat yang diharapkan oleh pelanggan dari sebuah produk atau jasa tertentu. Biaya pelanggan total adalah sekumpulan biaya yang diharapkan oleh konsumen yang dikeluarkan untuk mengevaluasi, mendapatkan, menggunakan dan membuang produk atau jasa.

Selanjutnya Oliver (1999: 92) menjelaskan bahwa nilai produk (product value) dapat dirasakan oleh konsumen sewaktu konsumen membandingkan antara kinerja produk yang berdasarkan utilitasnya dengan biaya yang dikeluarkan (acquisition cost), seperti finansial, psikologis, dan upaya untuk mendapatkan produk tersebut. Sedangkan menurut konsumen, nilai produk identik dengan empat hal yaitu : (1) value is low price; (2) value is whatever I want in a product; (3) value is the quality I get for the price I pay, and (4) Value is what I get for what I give

Monroe (dalam Kristanto, 2005: 16) mengungkapkan bahwa untuk menilai apakah kinerja produk sebuah merek mampu menciptakan nilai, didasari oleh empat komponen dari perceived value yaitu biaya, nilai tukar, estetika, dan fungsi relatif. Dalam penelitian ini penulis menggunakan konsep nilai produk yang dikemukakan oleh Monroe penjelasan sebagai berikut:

\section{Biaya (cost)}

Ialah total uang yang dikeluarkan atau dibayarkan konsumen untuk memperoleh dan mengkonsumsi sebuah produk. Biaya yang harus dikeluarkan oleh konsumen selain harga beli adalah biaya-biaya perawatan (post-purchase) selama mengkonsumsi produk tersebut. Dalam penelitian ini dimensi biaya diukur dengan indikator bahwa biaya yang dikeluarkan untuk menggunakan sepeda motor dapat menghemat biaya transporatsi yang harus dikeluarkan.

\section{Nilai pertukaran (exchange value)}

Adalah nilai yang diterima oleh pelanggan berhubungan dengan merek dan kemudahan yang diperoleh konsumen dalam mengkonsumsi sebuah produk. Citra positif terhadap sebuah merek dan kemudahan akan berdampak pada tertanamnya loyalitas dan menciptakan value. Dalam penelitian ini dimensi nilai tukar diukur dengan indikator bahwa harga yang dikeluarkan untuk membeli sepeda motor sesuai dengan kualitas yang diperoleh.

\section{Estetika}

Adalah nilai dimana konsumen merasa senang dan nyaman terhadap produk yang digunakannya. Indikator kenyamanan produk terlihat pada bentuk, desain, dan interior. Dalam penelitian ini dimensi estetika diukur dengan indikator model sepeda motor yang ditawarkan sangat menarik dan model tersebut dapat mendukung aktifitas sehari-hari konsumennya.

\section{Fungsi secara relatif}

Adalah bagaimana sebuah produk digunakan, serta kemampuannya dalam mereduksi biaya atau menghasilkan keuntungan tertentu bagi konsumen. Kualitas sebuah produk secara relatif memiliki fungsi tertentu yang bersifat intangible sejalan dengan jangka waktu atau cara konsumen menggunakan produk tersebut seperti irit bahan bakar, mesin awet, dan harga jual relatif stabil. Dalam penelitian ini dimensi ini diukur dengan indikator sepeda motor dapat meningkatkan produktifitas, dapat mengatasi kemacetan dan lebih cepat dari mobil transportasi umum.

Sedangkan Sweeney dan Soutar (2001: 75) mengembangkan 19 item skala ukuran customer perceived value. Skala 
yang disebut PERVAL tersebut dimaksudkan untuk menilai persepsi pelanggan terhadap nilai suatu produk konsumen tahan lama. Sweeney dan Soutar (2001: 77) berpendapat bahwa dimensi nilai terdiri dari 4 aspek utama yaitu:

- Emotional value, yaitu utilitas yang berasal dari perasaan atau afektif/emosi positif yang ditimbulkan dari mengkonsumsi produk.

- Social value, yaitu utilitas yang didapatkan dari kemampuan produk untuk meningkatkan konsep diri sosial kn sumen.

- Quality/Performance value, yaitu utilitas yang didapatkan dari produk dikarenakan reduksi biaya jangka pendek dan biaya jangka panjang.

- Price/Value for money, yakni utilitas yang diperoleh dari persepsi terhadap kualitas dan kinerja yang diharapkan atas produk.

Menurut Woodruf (dalam Kristanto, 2005: 17) mengemukakan bahwa konsep nilai produk mempunyai hubungan yang erat dengan kepuasan konsumen, dimana nilainilai yang dirasakan saat mengkonsumsi produk akan membentuk kepuasan konsumen, dan kepuasan konsumen ini berpengaruh terhadap loyalitas konsumen.

Selanjutnya Nauman (dalam Sylvia, 2003: 22) tujuan utama dari semua bisnis seharusnya adalah memberikan nilai pelanggan yang tinggi karena pelanggan membuat keputusan berdasarkan nilai yang diterima. Pelanggan akan membeli produk atau jasa dari perusahaan yang mereka yakini menawarkan nilai pelanggan yang tinggi. Bila kinerja produk melebihi harapan konsumen maka dapat tercipta kepuasan konsumen. Pendapat ini juga didukung oleh Howard dan Sheth (dalam Sylvia, 2003: 54) yang menyatakan bahwa persepsi nilai konsumen merupakan faktor penentu kepuasan konsumen. Lebih lanjut Fornell (dalam Sylvia, 2003: 59) juga mengatakan bahwa persepsi nilai konsumen merupakan faktor penentu kepuasan konsumen. Para penjual dapat meningkatkan persepsi nilai dengan meningkatkan persepsi pembeli terhadap nilai atau kualitas produk.

\section{Kualitas Pelayanan}

Menurut Zeithaml, et. al. (dalam Rizan, 2005: 113) kualitas pelayanan sebuah produk atau jasa akan terwujud jika harapan konsumen sesuai dengan kinerja pelayanan yang diberikan provider. Jika terjadi ketidaksesuaian antara kinerja pelayanan dengan harapan konsumen akan menimbulkan gap yang dapat mengurangi persepsi positif konsumen terhadap produk atau jasa. Kualitas pelayanan dan promosi menjadi faktor kunci menciptakan loyalitas pelanggan.

Parasuraman (dalam Rizan, 2005:
116) mengemukakan bahwa perlu diperhatikan lima determinan oleh provider, yaitu: kehandalan, daya tanggap, jaminan, empati, dan bukti fisik.

- Kehandalan: the ability to perform promised service dependably and accurately.

- Daya tanggap: the willingness to help customers and to provide prompt service.

- Jaminan: the knowledge and courtesy of employees and their ability to convey trust and confidence.

- Empati: the provision of caring, individualized attention to customers.

- Bukti fisik: the appereance of physical facilities, equipment, personnel, and communication material.

Menurut penelitian Sabihaini (2002: 33) yang menyimpulkan bahwa peningkatan kualitas pelayanan akan memberikan dampak yang baik untuk meningkatkan loyalitas. Kualitas pelayanan memiliki pengaruh langsung terhadap loyalitas dan 
mempengaruhi loyalitas melalui kepuasan. Gronroos (1990: 176) mengemukakan bahwa pada dasarnya kualitas pelayanan memiliki 2 (dua) dimensi, yaitu: Technical or outcome dimension and functional or process related dimension. Selanjutnya dikemukakan juga bahwa terdapat empat faktor yang mempengaruhi kualitas pelayanan, yaitu:

- Menjaga dan memperhatikan, bahwa pelanggan akan merasakan karyawan dan sistem operasional dapat menyelesaikan problem mereka.

- Spontanitas, dimana karyawan menunjukan keinginan untuk menyelesaikan masalah pelanggan.

- Penyelesaian masalah, karyawan yang berhubungan langsung dengan pelanggan harus memiliki kemampuan untuk menjalankan tugas berdasarkan standar yang ada, termasuk pelatihan yang diberikan untuk dapat memberikan pelayanan yang lebih baik.

- Perbaikan, apabila terjadi hal-hal yang tidak diinginkan harus mempunyai personel yang dapat menyiapkan usahausaha khusus untuk mengatasi kondisi tersebut.

\section{Kepuasan Konsumen}

Solomon (2004: 126) berpendapat bahwa kepuasan konsumen ditentukan melalui keseluruhan perasaan atau perilaku seseorang tentang sebuah produk setelah membeli dan mengkonsumsinya. Kepuasan yang diperoleh konsumen tidak lepas dari persepsi konsumen tentang kualitas produk. Kotler (2003: 61) menambahkan bahwa kepuasan konsumen adalah tingkatan perasaan seseorang setelah mengkonsumsi sebuah produk, dengan membandingkan antara performa produk dengan apa yang diharapkan. Oleh karena itu kepuasan dapat dibagi menjadi tiga tingkatan yaitu:
- Tidak puas (dissatisfied), terjadi bila performa produk yang dirasakan lebih kecil daripada harapan konsumen.

- Puas (satisfied), terjadi apabila performa produk yang dirasakan sebanding dengan yang diharapkan konsumen.

- Sangat puas (highly satisfied), terjadi saat konsumen merasakan performa produk melebihi dari apa yang diharapkan sebelumnya.

Kepuasan konsumen identik dengan nilai pelanggan (customer value). Salah satu pendekatan yang dapat menjelaskan perbedaan antara kepuasan dan customer value adalah means-end-value hierarchy model (MEVHM). MEVHM digunakan dalam disiplin ilmu pemasaran untuk menjelaskan bagaimana konsumen merasakan dan mengevaluasi produk yang digunakannya, berdasarkan atribut - atribut yang ada. Model hirarki ini terdiri dari dua tingkatan sebelum tercapai consumer value yaitu; kelengkapan atribut produk dan keuntungan yang diperoleh konsumen saat menggunakannya. Atribut produk meliputi kemudahan dalam penggunaan, kesesuaian dengan spesifikasi yang ditawarkan, tahan lama, hemat biaya, dan kelengkapan informasi. Sedangkan keuntungan yang didapat dari produk terdiri dari efektifitas pengiriman, komunikasi yang baik, dan pelayanan tambahan. Apabila kedua tahap terlewati maka akan tercapai kepuasan konsumen.

Dari Gambar 1 di bawah ini dapat dijelaskan bahwa kepuasan konsumen adalah komponen utama pembentuk nilai. Tanpa tercapainya kepuasan, maka tidak mungkin konsumen menilai bahwa sebuah produk dengan merek tertentu memiliki nilai. Gale (1997: 98) mempresentasikan bahwa customer value terbentuk dari kepuasan konsumen, yang merupakan integrasi dari dua faktor yaitu kualitas dan total biaya yang harus dikeluarkan oleh 
konsumen. Penilaian kualitas terdiri dari keunggulan produk, layanan pelanggan, citra merek, dan hubungan relasional. Keunggulan produk merupakan konsistensi penjagaan mutu dan kualitas oleh penyedia produk dan jasa. Layanan pelanggan merupakan kepedulian penyedia produk kepada konsumen yang berkaitan dengan utilisasi produk selama masa kepemilikan. Citra merek berkaitan dengan kemampuan perusahaan untuk menciptakan citra positif terhadap merek tersebut yang seringkali dijadikan alasan dasar oleh konsumen sebelum pembelian sebuah barang atau jasa. Penelitian ini menggunakan teori Gale (1997: 98-99) untuk membuat butir-butir pertanyaan dalam kuesioner karena relevan dengan penelitian yang dilakukan. Gale
(1997: 114), selanjutnya, menjelasakan bahwa kepuasan konsumen terdiri dari dua dimensi utama, yaitu:

- Kepuasan terhadap kualitas: dalam penelitian ini dimensi kepuasan terhadap kualitas diukur dengan indikator puas terhadap merek sepeda motor yang dibeli, nama besar merek sesuai dengan kualitas yang diterima, puas terhadap kualitas pelayanan bengkel dan dealer sepeda motor.

- Total biaya yang harus dikeluarkan konsumen: dalam penelitian ini dimensi total biaya diukur dengan indikator harga yang dikeluarkan konsumen seimbang dengan jaminan garansi yang diberikan.

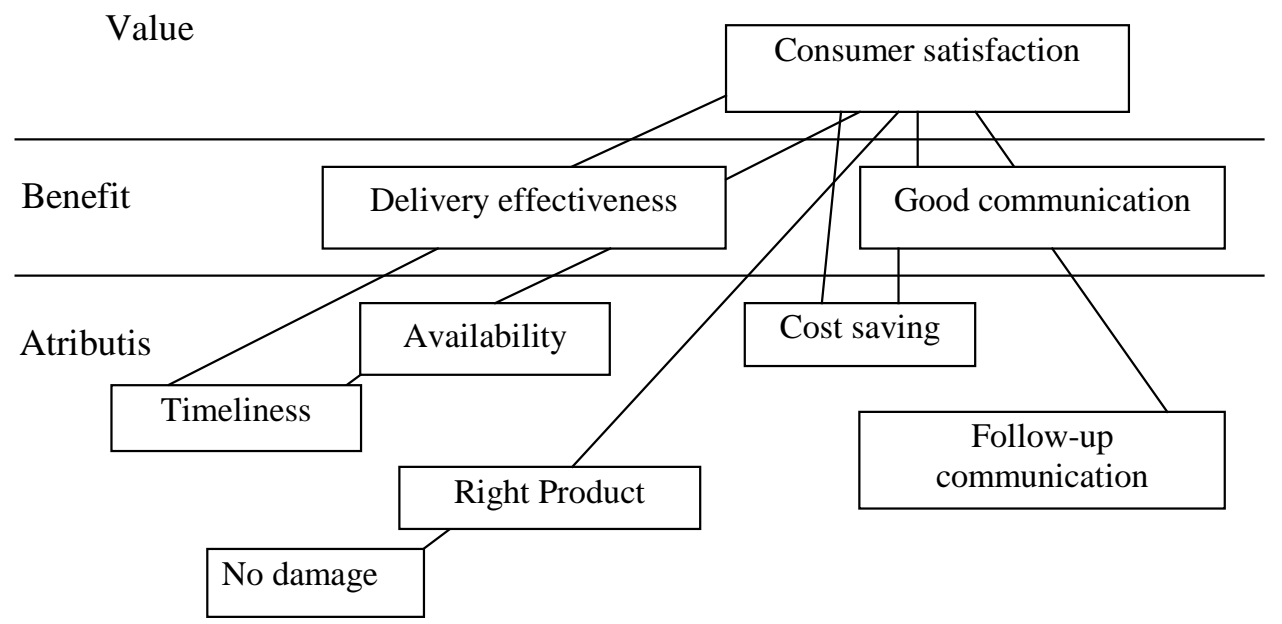

Gambar 1. Means-end value hierarchy model (MEVHM) 
Menurut Spreng (dalam Sylvia, 2003: 57) mengemukakan bahwa kepuasan total konsumen ditentukan oleh kepuasan terhadap atribut produk, kepuasan terhadap informasi yang diperoleh, dan persepsi terhadap kinerja produk. Kepuasan terhadap atribut merupakan penilaian subyektif konsumen sebagai hasil dari observasi terhadap kinerja atribut. Kepuasan informasi didefinisikan sebagai penilaian kepuasan subyektif terhadap informasi yang digunakan dalam pemilihan produk. Sedangkan persepsi terhadap kinerja merupakan kepercayaan terhadap atribut produk, tingkatan atribut, atau hasil. Cronin dan Taylor (dalam Rizan, 2005: 168) menunjukkan bahwa kepuasan konsumen dipengaruhi oleh kualitas pelayanan. Hal ini juga didukung dengan penelitian yang dilakukan oleh Bloemer dan Pauwels (1998 yang berpendapat bahwa terdapat hubungan yang erat antara kualitas pelayanan terhadap kepuasan dan loyalitas konsumen. Selanjutnya hasil penelitian Kristanto (2005: 69) menunjukan bahwa kepuasan konsumen di pengaruhi oleh asosiasi merek, nilai produk, dan kualitas pelayanan dealer. Inman dan Zeelenberg (dalam Sylvia, 2003: 78) mengemukakan bahwa kepuasan konsumen mempengaruhi loyalitas pelanggan.

\section{Loyalitas Konsumen}

Oliver (Sivadas, 2000: 77) mendefinisikan loyalitas adalah suatu komitmen yang kuat untuk melakukan pembelian ulang atau berlangganan suatu produk atau pelayanan secara konsisten, serta tidak mudah terpengaruh pada lingkungan yang ada atau upaya aktivitas pemasaran para pesaing, serta aspek-spek lain yang dapat mendorong pelanggan untuk beralih ke perusahaan lain. Karakteristik pelanggan yang loyal adalah: (1) Melakukan pembelian ulang secara teratur, (2) Membeli di luar lini produk/jasa yang ada, (3) Merekomendasikan produk/jasa yang dikomsumsi kepada orang lain, (4) Menunjukan resistensi sehingga tidak perpengaruh oleh daya tarik produk sejenis dari pesaing (Griffin, 1995: 31).

Kesesuaian antara kualitas penyampaian jasa dan nilai pelayanan diharapkan dapat meningkatkan loyalitas pelanggan. Hill (1996: 6) mendefinisikan loyalitas pelanggan sebagai suatu perilaku yang ditujukan dengan pembelian rutin didasarkan pada unit pengambilan keputusan. Keuntungan bagi perusahaan memiliki konsumen loyal adalah; (1) Mengurangi biaya pemasaran, (2) Mengurangi biaya transaksi, (3) Mengurangi biaya penggantian konsumen, (4) Meningkatkan penjualan, (5) Informasi dari mulut ke mulut yang positif, dan (6) mengurangi biaya kegagalan.

Berdasarkan uraian di atas, maka dapat dirumuskan hipotesis penelitian sebagai berikut;

$\mathbf{H}_{\mathbf{1}}$ : Terdapat pengaruh yang signifikan antara asosiasi merek, nilai produk dan koalitas pelayanan terhadap kepuasan konsumen.

$\mathbf{H}_{2}$ : Terdapat pengaruh yang signifikan antara asosiasi merek, nilai produk dan kualitas pelayanan terhadap loyalitas konsumen.

$\mathbf{H}_{3}$ : Terdapat pengaruh yang signifikan antara kepuasan konsumen terhadap loyalitas konsumen.

$\mathbf{H}_{\mathbf{4}}$ : Terdapat pengaruh yang signifikan antara asosiasi merek, nilai produk dan kualitas pelayanan baik secara langsung ataupun melalui kepuasan terhadap loyalitas konsumen.

Berdasarkan hipotesa di atas, maka dapat digambarkan paradigma/model penelitian ini sebagai berikut: 


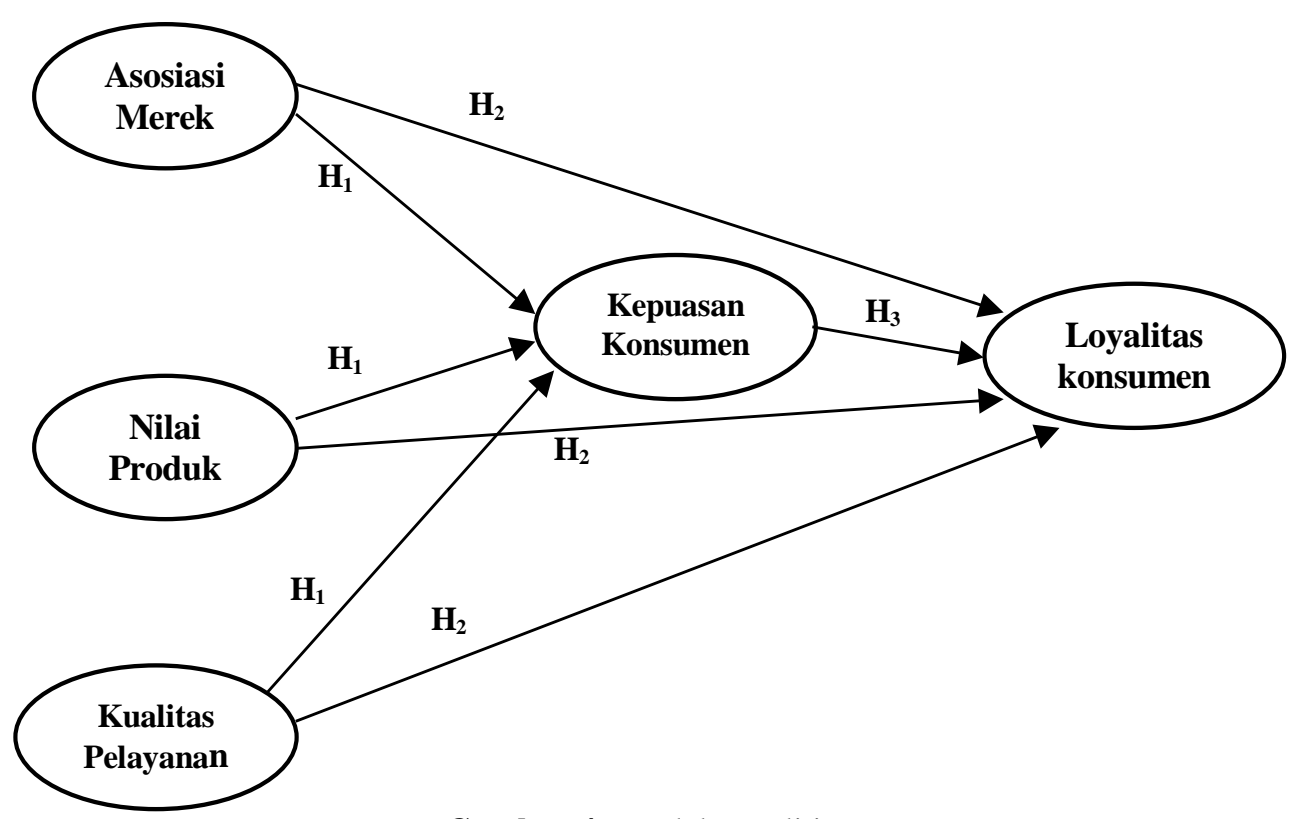

Gambar 4: Model Penelitian

Tabel 4: Populasi dan Teknis Penentuan Sampel

\begin{tabular}{cccc}
\hline Merek & Populasi & \% & Sampel \\
\hline Honda & 74.140 & 56,63 & 113 \\
Yamaha & 42.163 & 32,19 & 64 \\
Suzuki & 14.643 & 11,18 & 23 \\
Total & $\mathbf{1 3 0 . 9 4 6}$ & $\mathbf{1 0 0}$ & $\mathbf{2 0 0}$ \\
\hline
\end{tabular}

Sumber: Diolah dari data Kantor Samsat Kabupaten Bekasi

\section{METODOLOGI PENELITIAN}

Populasi penelitian adalah para pengguana sepeda motor merek Honda, Yamaha, dan Suzuki di Bekasi. Pengambilan sampel dilakukan dengan probability sampling dengan teknik yang dinamakan stratified sampling secara proporsional. Peneliti membagi populasi pemakai sepeda motor merek yang diteliti (Honda, Yamaha, dan Suzuki). Kemudian proporsi sub populasi dijadikan angka proporsional terhadap besarnya sampel yang telah ditentukan terlebih dahulu yaitu 200 responden.

Jumlah sampel ini telah memenuhi persyaratan sampel ideal yang harus dipenuhi dalam penggunaan alat analisis
Structural Equation Modeling (SEM), yaitu berkisar antara 100 sampai dengan 200 sampel atau 5-10 kali indikator (Hair and Black, 1998: 604; Ferdinand, 2002: 43; Bachrudin dan Tobing, 2003: 68). Adapun proporsi sampel penelitian ini nampak seperti pada Tabel 4.

Instrumen penelitian (kuesioner) penelitian menggunakan skala Likert, mulai dari 1 (sangat tidak setuju), 2 (tidak setuju), 3 (cukup setuju), 4 (setuju), 5 (sangat setuju). Sebelum kuesioner tersebut diedarkan harus diuji terlebih dahulu dengan pra survey sebanyak 30 responden. Hasil uji validitas dan reliabilitas dari pra survey menunjukkan bahwa indikator dan variabel 
penilitian ini valid dan reliabel. Hal ini menunjukkan bahwa instrumen penelitian tersebut layak untuk dipergunakan dalam pengumpulan data.

\section{HASIL PENELITIAN \& PEMBAHASAN Deskript}

Jenis sepeda motor yang paling digemari konsumen adalah sepeda motor jenis bebek kemudian baru diikuti dengan jenis sport dan skutik. Dan atribut sepeda motor yang menjadi dasar pertimbangan konsumen ketika memilih sepeda motor adalah atribut bahan bakar yang irit dan mesin yang awet. Dimensi yang berpengaruh kuat terhadap asosiasi merek adalah dimensi perilaku dan dimensi manfaat. Untuk variabel nilai produk, dimensi yang berpengaruh kuat adalah dimensi biaya, nilai tukar, estetika dan fungsi relatif. Dimensi yang berpengaruh kuat terhadap kualitas pelayanan adalah fisik dan empati. Dimensi yang berpengaruh kuat terhadap kepuasan pelayanan adalah kepuasan terhadap kualitas dan total biaya yang harus dikeluarkan. Sedangkan dimensi yang berpengaruh kuat terhadap loyalitas adalah pembelian ulang, kebal terhadap pesaing, perluasan lini pembelian dan minat merekomendasikan.

\section{Hypothesis Testing}

Hipotesis 1; Terdapat pengaruh yang signifikan antara asosiasi merek, nilai produk dan kualitas pelayanan terhadap kepuasan konsumen

Dari hasil output Lisrel menunjukan bahwa model tersebut sudah fit sehingga model layak untuk digunakan karena memiliki nilai GFI $0.92>0.90$. Hasil pengujian dapat dilihat dari output Lisrel sebagai berikut:

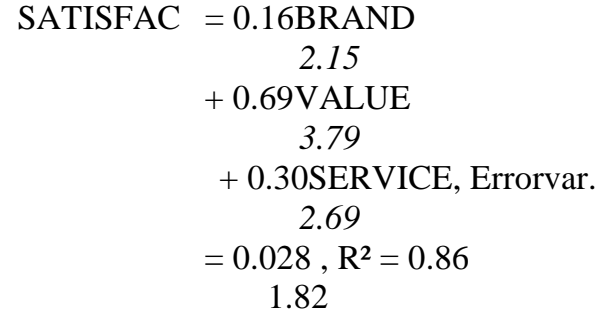

Dari persamaan tersebut dapat diinterpretasikan bahwa: jika asosiasi merek meningkat satu unit sedangkan nilai produk dan pelayanan dianggap tetap maka variabel kepuasan akan meningkat 0.16 unit, begitu juga jika nilai produk meningkat satu unit sedangkan asosiasi merek dan pelayanan tetap maka variable kepuasan akan meningkat 0.69 unit, dan jika pelayanan meningkat satu unit sedangkan asosiasi merek dan nilai produk tetap maka variable kepuasan akan meningkat 0.30 unit. Dari nilai $\mathrm{t}$ statistik (yang dicetak miring) > 1.96 maka $\mathrm{H0}$ ditolak atau terima $\mathrm{H} 1$ atau dapat disimpulkan bahwa asosiasi merek, nilai produk dan kualitas pelayanan berpengaruh secara signifikan terhadap kepuasan konsumen. Besarnya koefisien determinan dari model ini adalah $\mathrm{R}^{2}=0.86=86 \%$. Hal ini berarti kepuasan konsumen dapat dijelaskan sebesar $86 \%$ oleh asosiasi merek, nilai produk dan kualitas pelayanan, selebihnya $14 \%$ dijelaskan oleh variabel lain.

Besarnya koefisien pengaruh masingmasing variabel terhadap kepuasan dapat dilihat dari hasil output Lisrel dan gambar SEM berikut:

GAMMA

\begin{tabular}{cccc}
\multirow{2}{*}{ Satisfaction } & BRAND & VALUE & SERVICE \\
\cline { 2 - 3 } & 0.21 & 0.52 & 0.38
\end{tabular} 


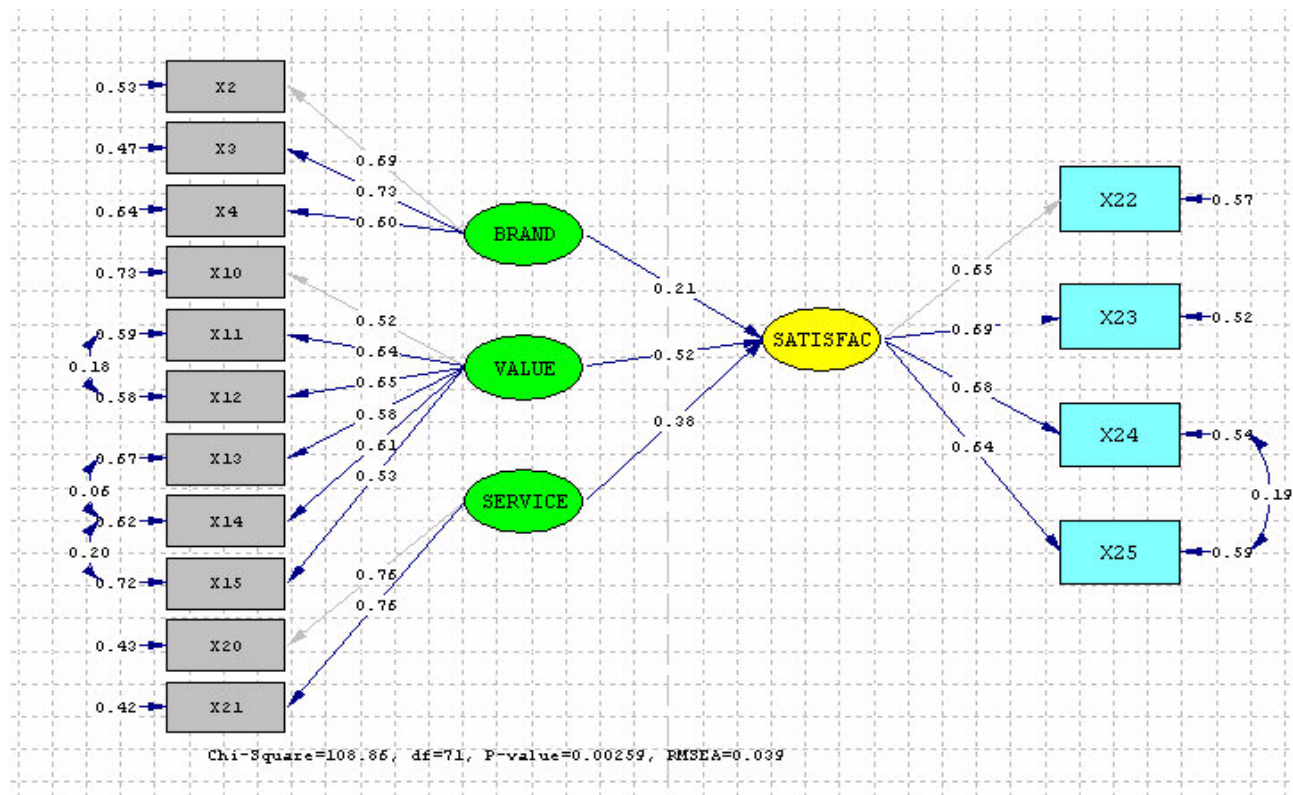

Sumber: Hasil pengolahan data dengan Lisrel 8.7

Gambar 5: Model SEM Hipotesis 1

Hipotesis 2; Terdapat pengaruh yang signifikan antara asosiasi merek, nilai produk dan kualitas pelayanan terhadap loyalitas konsumen. Dari hasil output terlihat bahwa model ini sudah fit sehingga layak digunakan karena memiliki nilai GFI $0.92>0.90$. adapun hasil output Lisrel sebagai berikut:

Structural Equations

$$
\begin{aligned}
\text { LOYALTY } & =0.13 \mathrm{BRAND} \\
& 1.20 \\
& +0.45 \mathrm{VALUE} \\
& 2.05 \\
& +0.50 \text { SERVICE, Errorvar. } \\
& 3.33 \\
& =0.18, \mathrm{R}^{2}=0.51 \\
& 4.48
\end{aligned}
$$

Dari persamaan tersebut dapat diinterpretasikan bahwa: jika asosiasi merek naik satu unit dan nilai produk dan pelayanan dianggap tetap maka loyalitas akan naik sebesar 0.13 unit, jika nilai produk naik satu unit sedangkan asosiasi merek dan pelaya- nan dianggap tetap maka loyalitas akan naik 0.45 unit, jika pelayanan naik satu unit sedangkan asosiasi merek dan nilai produk dianggap tetap maka loyalitas akan naik 0.50 unit.

Dari nilai t statistik dapat disimpulkan bahwa $\mathrm{H} 0$ ditolak atau terima $\mathrm{H} 1$ atau dengan kata lain terdapat pengaruh yang signifikan antara asosiasi merek, nilai produk dan kualitas pelayanan terhadap loyalitas, dengan koefisien determinasi sebesar $\mathrm{R}^{2}=0.51$ atau $51 \%$. Namun jika kita perhatikan besar pengaruh masing-masing konstruk tersebut maka dapat diketahui bahwa nilai produk dan pelayanan berpengaruh secara signifikan terhadap loyalitas karena nilai t statistik $>1.96$. Akan tetapi asosiasi memiliki pengaruh yang tidak signifikan yaitu hanya memiliki nilai $\mathrm{t}$ statistik $1.20<1.96$. Hal ini dapat berarti telah terjadi anomali karena pada penelitian yang dilakukan Husnur Rifqi asosiasi merek sangat berpengaruh terhadap loyalitas 
konsumen tetapi dalam penelitian ini asosiasi merek tidak berpengaruh secara signifikan terhadap loyalitas. Besarnya pengaruh masing-masing konstruk terhadap loyalitas adalah sebagai berikut:

\section{GAMMA \\ LOYALTY $\frac{\text { BRAND }}{0.13}$ - VALUE}

Bahwa besarnya pengaruh asosiasi merek terhadap loyalitas sebesar 0.13 dan nilai produk terhadap

loyalitas sebesar 0.27 dan pengaruh pelayanan terhadap loyalitas sebesar 0.46 . gambar model SEM berikut:

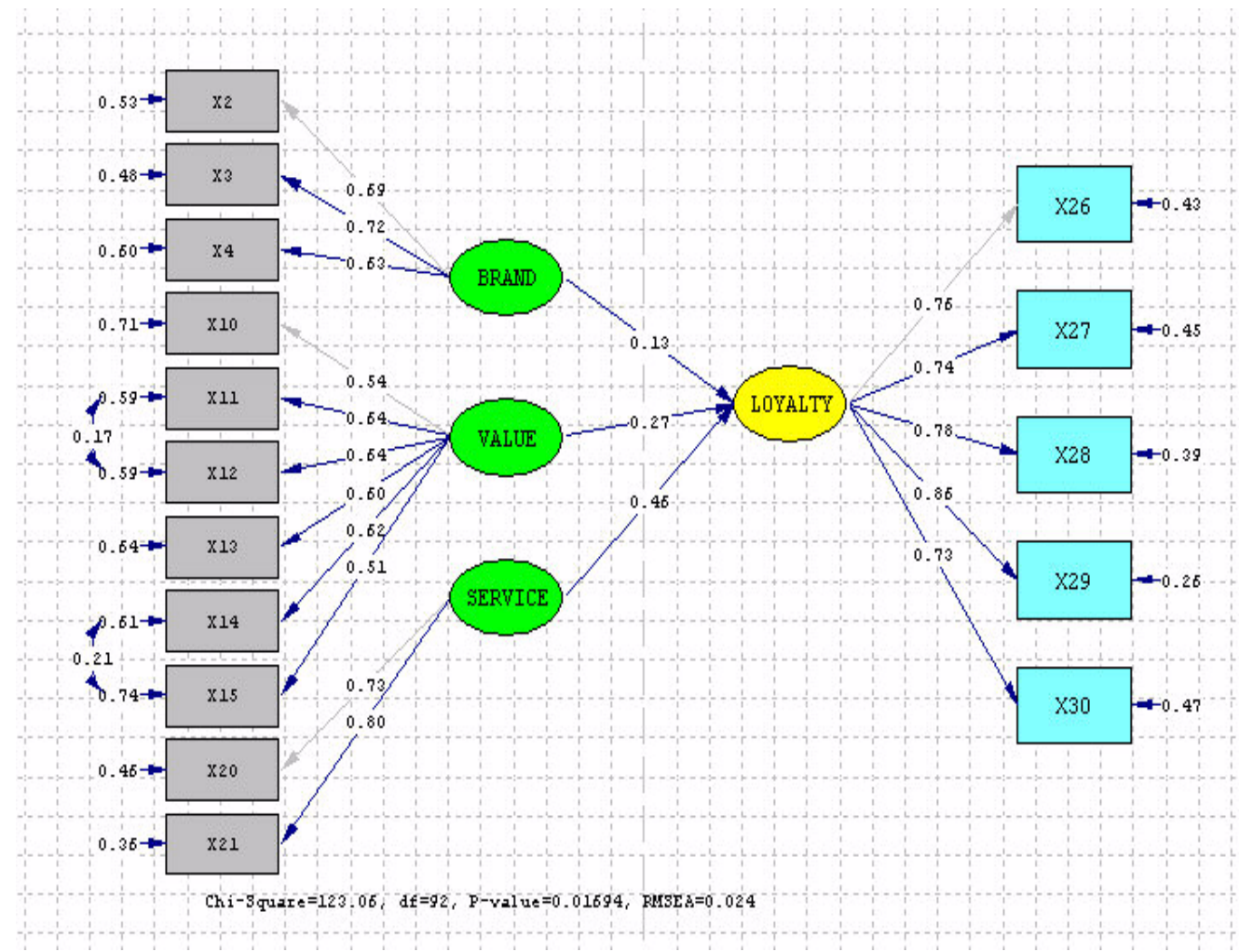

Sumber: Hasil pengolahan data dengan Lisrel 8.7

Gambar 6: Model SEM Hipotesis 2 
Hipotesis 3; Terdapat pengaruh yang signifikan antara kepuasan konsumen terhadap loyalitas konsumen. Dari hasil output Lisrel dapat dilihat bahwa model tersebut sudah fit sehingga model layak untuk digunakan karena memiliki nilai GFI $0.97>0.90$.

Hasil out put Lisrel adalah;

Structural Equations

LOYALTY $=1.11$ SATISFAC,Errorvar.

$$
\begin{gathered}
6.34 \\
=0.14, \mathrm{R}^{2}=0.62 \\
4.68
\end{gathered}
$$

Dari persamaan tersebut dapat diinterpretasikan bahwa jika kepuasan naik satu unit maka loyalitas akan naik sebesar 1.11 unit.
Dari nilai t statistik > 1.96 sehingga dapat disimpulkan bahwa H0 ditolak atau terima $\mathrm{H} 1$ atau dengan kata lain terdapat pengaruh yang signifikan antara kepuasan terhadap loyalitas dengan koefisien determinasi sebesar $\mathrm{R}^{2}=0.62$ atau $62 \%$. Jadi tingkat loyalitas konsumen dijelaskan oleh kepuasan konsumen sebesar $62 \%$. Besarnya pengaruh konstruk kepuasan adalah:

\section{GAMMA}

$$
\text { LOYALTY } \quad 0.79
$$

Adapun gambar struktural path diagram dari model SEM adalah sebagai berikut:

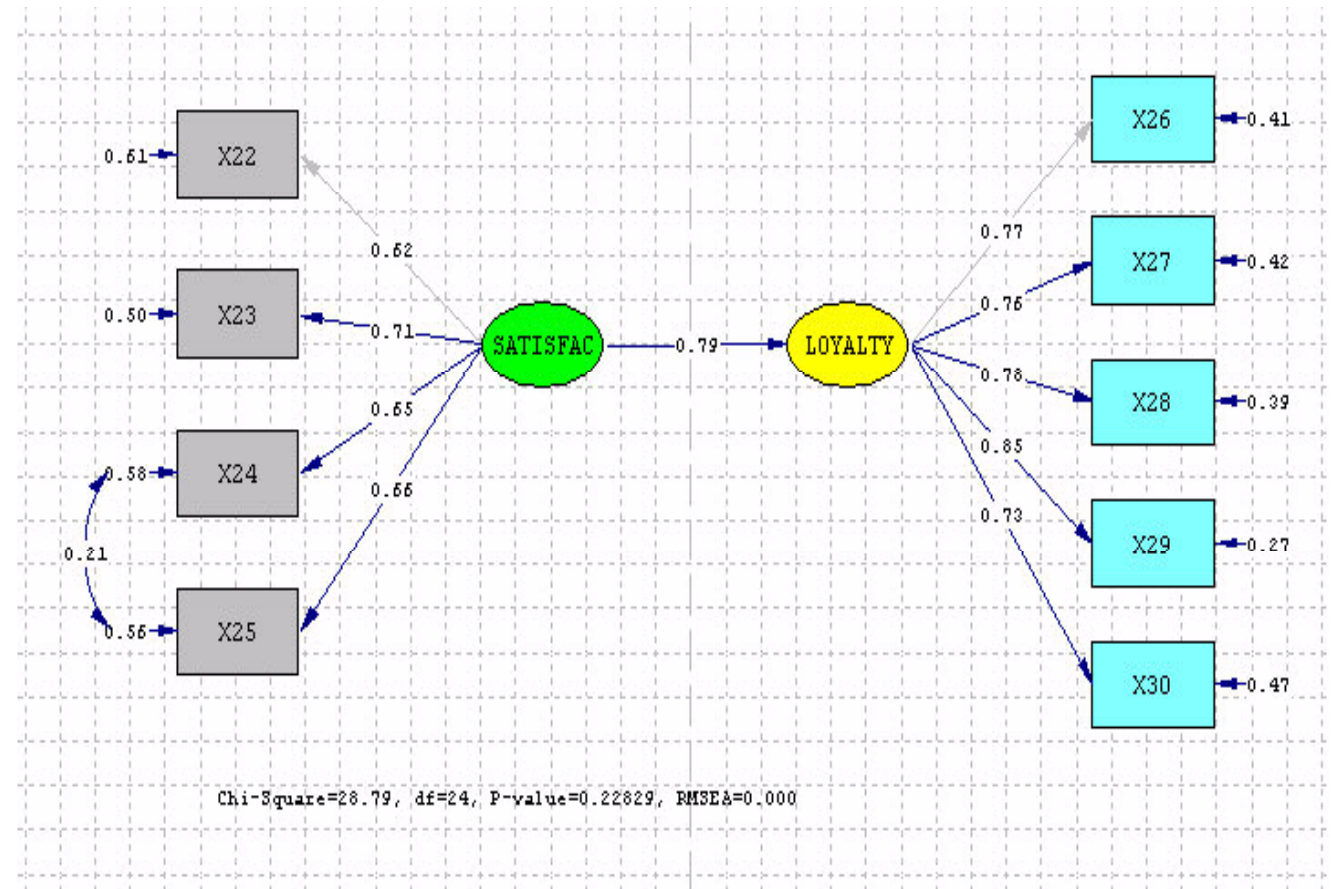

Sumber: Hasil pengolahan data dengan Lisrel 8.7

Gambar 7: Model SEM Hipotesis 
Hipotesis 4; Terdapat pengaruh yang signifikan antara asosiasi merek, nilai produk dan kualitas pelayanan baik secara langsung ataupun melalui kepuasan terhadap loyalitas konsumen.

Dari hasil uji kecocokan model yang dihasilkan output Lisrel terlihat bahwa model tersebut layak digunakan karena memiliki nilai GFI 0.90. Adapun hasil out put Lisrel sebagai berikut;

Structural Equations

$$
\begin{aligned}
1 . \mathrm{SATISFAC}= & 0.11 \mathrm{BRAND} \\
& 1.55 \\
& +0.59 \mathrm{VALUE} \\
& 3.53 \\
& +0.37 \mathrm{SERVICE}, \text { Errorvar. } \\
& 3.30 \\
& =0.030, \mathrm{R}^{2}=0.84 \\
& 2.11
\end{aligned}
$$

\section{LOYALTY}

$$
\begin{aligned}
& =1.11 \text { SATISFAC, Errorvar. } \\
& 7.26 \\
& =0.16, \mathrm{R}^{2}=0.60 \\
& 5.27
\end{aligned}
$$

Dari persamaan 1 di atas dapat diinterpretasikan bahwa: (1) jika asosiasi merek naik satu unit sedangkan nilai produk dan pelayanan tetap maka kepuasan akan naik sebesar 0.11 satuan. Implikasi managerial dari fenomena ini adalah diperlukan suatu strategi pemasaran yang baik untuk dapat meningkatkan asosiasi merek produknya agar berdampak pada terjadinya peningkatan kepuasan konsumen; (2) jika nilai produk naik satu unit sedangkan asosiasi merek dan pelayanan tetap maka kepuasan akan naik 0.59 satuan. Implikasi managerial dari fenomena ini adalah diperlukan suatu upaya yang optimal untuk meningkatkan nilai produk yang dimiliki agar dapat meningkatkan kepuasan konsumen; dan (3) jika pelayanan naik satu unit sedangkan asosiasi merek dan nilai produk tetap maka kepuasan akan naik sebesar 0.37 satuan. Implikasi managerial dari fenomena ini adalah dipertlukan upaya optimal untuk meningkatkan kualitas pelayanan yang disajikan lebih baik agar mampu meningkatkan kepuasan konsumen. Sedangkan jika dilakukan analisis dari persamaan 2 dapat diintepretasikan bahwa jika kepuasan konsumen naik sebesar satu satuan maka akan berimplikasi pada peningkatan loyalitas konsumen sebesar 1.11 satuan.

Jika dilihat nilai $\mathrm{t}$ statistik ketiga variabel tersebut adalah asosiasi merek 1.55, nilai produk 3.53, dan pelayanan 3.30. Dari nilai $t$ statistik tersebut nampak bahwa variabel nilai produk dan kualitas pelayanan memiliki pengaruh yang signifikan secara tidak langsung terhadap loyalitas karena memiliki nilai $\mathrm{t}>1.96$, sedangkan asosiasi merek tidak memiliki pengaruh signifikan secara tidak langsung terhadap loyalitas $(1.55<1.96)$.

\section{PENUTUP \\ Kesimpulan}

Jenis sepeda motor yang paling digemari konsumen adalah sepeda motor jenis bebek kemudian baru diikuti dengan jenis sport dan skutik. Dan atribut sepeda motor yang menjadi dasar pertimbangan konsumen ketika memilih sepeda motor adalah atribut bahan bakar yang irit dan mesin yang awet. Dimensi yang berpengaruh kuat terhadap asosiasi merek adalah dimensi perilaku dan dimensi manfaat. Untuk variabel nilai produk, dimensi yang berpengaruh kuat adalah dimensi biaya, nilai tukar, estetika dan fungsi relatif. Dimensi yang berpengaruh kuat terhadap kualitas pelayanan adalah fisik dan empati. Dimensi yang berpengaruh kuat terhadap kepuasan pelayanan adalah kepuasan terhadap kualitas dan total biaya yang harus dikeluarkan. Sedangkan dimensi yang berpengaruh kuat terhadap loyalitas adalah pembelian ulang, kebal terhadap pesaing, perluasan lini pembelian dan minat merekomendasikan produk. 
Asosiasi merek, nilai produk dan kualitas pelayanan berpengaruh secara signifikan terhadap kepuasan konsumen. Implikasi managerial dari fenomena ini menunjukan bahwa variabel independen tersebut merupakan faktor strategis yang harus dikelola dengan baik agar dapat meningkatkan kepuasan konsumen riel maupun konsumen potensial.

Terdapat pengaruh yang signifikan antara asosiasi merek, nilai produk dan kualitas pelayanan terhadap loyalitas konsumen. Implikasi managerial dari fenomena ini menunjukan bahwa variabel independen tersebut merupakan faktor strategis yang harus dikelola dengan baik karena selain berperan meningkatkan kepuasan konsumen riel maupun konsumen potensial, juga akan menciptakan dan mempertahankan loyalitas dari konsumen riel maupun potensial tersebut. Hal ini penting karena mendapatkan konsumen potensial sama sulitnya dengan mempertahankan konsumen riel.

Terdapat pengaruh yang signifikan antara kepuasan konsumen terhadap loyalitas konsumen. Implikasi managerial dari fenomena ini menunjukan bahwa kepuasan konsumen merupakan salah satu faktor strategis untuk menciptakan maupun mempertahankan loyalitas konsumen.

Terdapat pengaruh yang signifikan antara asosiasi merek, nilai produk dan kualitas pelayanan baik secara langsung ataupun melalui kepuasan terhadap loyalitas konsumen.

\section{Saran}

\section{Bagi Akademik}

Penelitian ini masih memiliki keterbatasan dalam pengambilan responden yang hanya dilakukan di wilayah Kabupaten Bekasi. Hal ini belum dapat menggambarkan kondisi seluruh wilayah Indonesia, untuk itu penulis menyarankan bagi penelitian selanjutnya untuk memperluas wilayah survei, misalnya perwakilan seluruh wilayah propinsi yang ada di Indonesia.

Penulis menyarankan bagi penelitian selanjutnya untuk mencari variabel lain yang mempengaruhi secara signifikan terhadap loyalitas selain asosiasi merek, nilai produk, kualitas pelayanan dan kepuasan konsumen.

Penelitian ini menggunakan data dari konsumen tiga merek sepeda motor sehingga untuk penelitian selanjutnya disarankan untuk melibatkan semua merek sepeda motor yang beredar di wilayah Indonesia. Untuk menguji konsistensi model penelitian ini maka perlu dilakukan replikasi penelitian dengan obyek penelitian yang berbeda $B a g i$ Pelaku Bisnis Fokuskan pengembangan produk terhadap sepeda motor jenis bebek karena jenis ini merupakan yang paling diminati konsumen.

Tingkatkan loyalitas konsumen dengan cara memberikan pelayanan yang terbaik terhadap konsumen dengan cara: adakan training secara teratur bagi tenaga lini depan dan pendukungnya, melengkapi dealer dan bengkel resmi dengan ruang tunggu yang nyaman dan memadai, melengkapi pelayanan service dengan membuka layanan hotline konsultasi sepeda motor, meningkatkan lama waktu garansi, menjalin hubungan yang lebih baik dengan berbagai klub dan komunitas merek sepeda motor tersebut dengan cara: mensponsori kegiatan komunitas dan klub merek tersebut, membuat website dan mailing list yang dapat digunakan sebagai media komunikasi antara produsen dan konsumen.

Tingkatkan teknologi sepeda motor yang dapat meningkatkan kepuasan konsumen seperti membuat sepeda motor yang irit bahan bakar, mesin yang awet, dan harga pantas.

Tingkatkan kegiatan yang dapat meningkatkan ingatan konsumen terhadap asosiasi merek sepeda motor dengan cara: mengadakan acara mudik gratis, mengadakan kejuaraan balap sepeda motor satu 
merek, mengadakan training safety riding, memberikan sponsor kepada pembalap yang berprestasi, mengadakan berbagai acara family gathering bagi konsumen sepeda motor, dan meningkatkan promosi baik di media above the line atau below the line.

\section{DAFTAR PUSTAKA}

Aaker, D.A. (1994). Managing Brand Equity. New York: The Free Press.

Aaker, D.A. and Jochimsthaler. (2000). Brand Leadership: The Next Level of The Brand Revolution. New York: New York Press.

Assael, H. (1995). Consumer Behaviour and Marketing Action. Fifth Edition. Cincinati : South West College Publishing.

Denada, S.T. (2003). Studi Mengenai Proses Adopsi Konsumen Pasca Masa Tayang Iklan Produk "Xon-Ce" di Surabay. Semarang : Jurnal Sain Pemasaran Indonesia Undip.

Dharmesta, B.S. (1999). Loyalitas Pelanggan: Sebuah Kajian Konseptual Sebagai Panduan Bagi Peneliti. Jurnal Ekonomi dan Bisnis Indonesia, 14, (3).

Engel, J.F. et. al. (1990). Consumer Behaviour. Sixth Edition. Montreal: The Dryden Press International Edition.

Ermina, M. (2004). Prospek Industri Sepeda Motor. Economic Review Journal. Jakarta.

Gale, T.B. (1997). Managing Customer Value: Creating Quality and Service That Customer Can See. New York : The Free Perss.

Ghozali, I. dan Fuad (2005). Structural Equation Modelling Teori, Konsep dan Aplikasi dengan Program
Lisrel. Semarang : Badan Penerbit Universitas Diponegoro.

Griffin, Jill. (1995). Customer Loyalty: How to Earn It, How to Keep It. New York, USA: Lexington Books.

Gronroos, C. (1990). Service Management and Marketing. Toronto, Massachusetts : Laxington Books.

Hair, et. al.. (1998). Multivariate Data Analysis. New York: PrenticeHall.

Hidayat, T. (2007). Majalah Marketing, 02/VII/Februari, Hal 15.

Keller, L.K. (2003). Strategic Brand Management. New Jersey: Prentice Hall.

Kristanto, A. (2005). Analisis Pengaruh Asosiasi Merek, Nilai Produk, dan Kualitas Pelayanan Terhadap Kepuasan, Serta Hubungannya Dengan Retensi Konsumen: Studi Mengenai Motor Merek Honda di Jakarta. Magister Manajemen UI, Jakarta.

Kotler, P. (2003). Marketing Management. Eleven Edition. New Jersey : Prentice Hall.

Maholtra, K.N. (2004). Riset Pemasaran. Edisi keempat. Jakarta: Indeks.

Maulana, P. (2007). Tabloid Otomotif, 29 Januari, Hal 17.

Michael D. et al. (2000). Improving Customer Satisfaction Loyalty and Profit. University of Michigan: Business School Management Series.

Mowen, J.C. dan M. Minor. (1998). Consumer Behavior, 5th Ed. Upper Saddle River, NJ: Prentice Hall, Inc. 
Muhibudin. Kamis 22 Maret (2007). www.republika.co.id.

Oliver, R.L. (1999). Satisfaction, a Behavioral Perspective on The Consumer. New York : McGraw Hill.

Pearson S. (1996). Building Brand Directly: Creating Business Value from Customer Relationship. Macmillam Business.

Pemda Kabupaten Bekasi, 12 Januari (2007). www.kab-bekasi.go.id

Rizan. M. (2005). Hubungan Kepemimpinan Transaksional dan transformasional Dengan Komitmen Organisasional Dalam Menciptakan Kepuasan Kerja Dan Kualitas Pelayanan Karyawan Gugus Depan Serta Pengaruhnya Terhadap Kepuasan Dan Loyalitas Konsumen. Disertasi Ilmu Ekonomi-Manajemen Universitas Padjadjaran. Bandung.

Rifqi, H. (2003). Analis Loyalitas Pengguna Sepeda Motor Honda di Kelurahan Patemon Surabaya. Tesis Magister Manajemen Univeritas Muhammadiyah. Malang.

Sekretariat AISI. 24 Januari (2007). www.aisi.co.id.

Susanto, A.B dan Himawan .W. (2004). Power Branding. Jakarta : Quantum.
Solomon, M. (2004). Consumer Behaviour: Buying, Having, Being. Six Edition. New Jersey: Prentice Hall.

Sabihaini. (2002). Analisis konsekuensi Keperilakuan Kualitas Layanan; Suatu Kajian Empirik. Usahawan, No. 02 Th xxxi. Pp. 29-36. Jakarta: Universitas Indonesia.

Singh, J. and Deepak .S. (2000). Agency and Trust Mechanisms in Customer Satisfaction and Loyalty Judgement. Journal of The Academy of Marketing Science, (28), 150-167.

Sitinjak T. (2004). Menaklukan Pasar Melalui Riset Ekuitas dan Perilaku Merek Jakarta: Gramedia Pustaka Utama.

Temporal, P. (2001). Branding in Asia, Revised Edition. John Willey \& Sons, ASIA Pte Ltd.

Travis, D. (2000). Emotional Branding: How Succesfull Brands Gain The Irrational Edge. Jakarta: Prima Venture.

Wilkie, W. L. (1994). Consumer Behavior. 3rd ed. John Wiley \& Sons, Inc.

Zeithaml, V.A. (2005). Consumer Perception of Price, Quality, and Value: A Means-End Model and Synthesis of Evidence. Journal of Marketing, Vol 52. 